\title{
Brownfield redevelopment: a business approach for regional collaboration
}

\author{
W. F. Schaefer, E. G. J. Blokhuis, Q. Han, J. Braas \\ \& C. J. T. M. Kokke \\ Eindhoven University of Technology, Department of Construction, \\ Management \& Engineering, The Netherlands
}

\begin{abstract}
Several problems can be distinguished when studying the general process of redevelopment of industrial areas in The Netherlands. Due to these problems - and combinations of these problems - redevelopment process fails or is severely delayed. In this article, an entrepreneurial approach for reconstruction of industrial areas in The Netherlands is advocated. The approach is based upon an explorative research project, examining relevant urban district development cases in The Netherlands and Sweden. Within this integral approach, all the aspects of the whole site are completely taken into account. This means that both the problems in public and private areas are addressed. The solutions need to be geared to one another and address the interests of all involved stakeholders. Thereby, we distinguish six major stakeholder groups: National Government, Province, Municipalities, Local Entrepreneurs, Investors and Development Companies. It is interesting to notify that there are three different governmental agencies involved, each having its own policy targets and rule-sets.

An ideal typical public-private 'regional development company' (RDC) is proposed and outlined for a specific region, located in the Province of NoordBrabant in The Netherlands. A major feature in this approach is the involvement of a number of different municipalities, each of them characterized as shareholder, similar to the local entrepreneurs. This research result was brought into a simulation experiment, testing the lay-out of the business organization. The outcomes of the experiment - showing an ideal design of a development company which can create an integral approach for restructuring industrial areas - are interesting and contribute to ongoing discussions concerning stagnating redevelopment of brownfields and industrial areas in The Netherlands.
\end{abstract}

Keywords: industrial area market, spatial planning approach, redevelopment process. 


\section{Introduction}

The restructuring of business locations in The Netherlands is needed, because they have become obsolete. In the "Nota Ruimte" [1] it is stated that a large part of the business locations is not adequate to today's standards. If business locations are redeveloped, revitalized or transformed the appearance of the urban area will be strongly improved [1]. The ministry of Finance has stated in 2004 that more that $20 \%$ of the total stock of business locations is dated, which amount to 21.670 hectare. In a more recent publication [2], approximately 32.000 hectare, $33 \%$ is indicated as dated locations. The execution of the restructuring has not been and is still not very successful. In the period 19902003, only 1.900 hectare is restructured. If it continues in this pace, it will take 200 years to restructure the current stock of obsolete business locations.

There are many different parties involved in the restructuring. In most cases, the local authorities have to take the initiative to realize a restructuring of a business location. The objective of this research is to design a development company, which can realize an integral approach for the restructuring of business locations.

\section{Research approach}

The major purpose of this research was to create a virtual pilot for the involved representatives of municipalities and investment institutions. Therefore a suitable organization design was required. The research was elaborated in 4 steps:

1. PROBLEM FINDING AND DATA: The first step is an analysis of international and national theories and case studies of development companies and the restructuring of business locations.

2. PRECONDITIONS: The results of the analysis will provide preconditions for the design of a regional development company.

3. ORGANIZATION DESIGN: With the determined preconditions the design of the development company is created. The design will have the shape of a business plan.

4. SIMULATION/TESTING: The different roles and mandates of involved participants, positioned within the proposed organization will be simulated in several redevelopment cases.

\section{Problem finding and data collection}

The Taskforce 'Redevelopment Business Location' [2] has determined the problems on business locations. They have described the following most important problems:

- Business locations are aging too rapidly;

- The supply of new business locations is too large and too inexpensive;

- The supply is not focused on the demand; and

- The supply of business sites is not very differentiated. 


\subsection{Finding a 'problem owner'}

The restructuring of business locations is complex and expensive. The national government and provinces acknowledge the problems of existing location and the restructuring of these sites. They want to stimulate municipalities and entrepreneurs to execute the restructuring. Municipalities and the established companies are not very willing to participate in the restructuring of the industrial sites. They experience the problems of existing business locations and some of the problems are acknowledged as disturbing. In the current system there are no benefits with the restructuring of business location for these parties. Investors have a limited role in the restructuring, because they will only participate if it results in opportunities.

The local governments are the main developers of industrial land and show no hesitation to develop new industrial estates. Because of the large supply of new estates many firms move to these sites leaving behind older industrial sites [3].

The increasing ageing of business locations and the difficulty of financing the restructuring are difficult issues. More companies are leaving the locations and the vacancy and the corruption is increasing. The restructuring of these business locations is needed, but the financial feasibility is a problem [4]. Traditionally the central national government is assigned to (re-) develop land in order to stimulate economic growth. At present national authorities do not have sufficient financial means and market parties are invited to share these development responsibilities, but as noted, they will only participate if it results in opportunities.

\subsection{Involved stakeholders}

The Government wants to change the current use of land for business locations, because there is a lot of criticism on the use of space in general. Approximately $17 \%$ of the land is used in The Netherlands. However, the experience is that The Netherlands is fully used and that there is not enough space. This means that there need to be another approach for the use of land. The VROM-raad suggests that the space on business sites can be used more efficiently and intensely.

The aging of existing business location is also problem for the Province. The Province is partially responsible. They have a social responsibility to stimulate the restructuring of industrial sites [5]. The province can play an important role in the restructuring of business locations. They can stimulate the restructuring by making funds available.

Local governments, Municipalities, are the main suppliers of building land in The Netherlands. They can plan and develop industrial estates themselves due to their statutory planning and land policy [3]. The municipality wants to have enough stock of business locations, because there is a belief that it will stimulate economic growth. The municipality is responsible for a sustainable economic growth in the community.

Entrepreneurs need to be involved to realize a restructuring of an industrial site. They need to be willing to cooperate in the development. It is a great help if the entrepreneurs are involved and willing to collaborate [6]. However, it is 
difficult to unite all the entrepreneurs. The entrepreneurs on a site often do not know each other and they are focused on executing activities for their own business.

Investors have a limited role in the market of business locations. There are different kinds of investors: property developers/contractors, just property developers or just investors. The company specific buildings have a low and hardly rising market value. Companies are not likely to move, due to the high cost. The circulation is very limited. There is little room for new investors. These aspects result in limited business locations for rent and the buildings do not make an attractable investment [7]. The role of these parties is slowly increasing, but still $75 \%$ of the supply of building land on industrial estates is developed by the local government [3].

\section{3 'The district development company'}

In The Netherlands there are several new initiatives to create private companies responsible for the development of areas. The first of these are the organisation of housing complexes, they make and enforce rules, collect assessments from all owners and maintain property. They function as private governments for the development. An interesting and useful organization example is the District Development Company (DDC). These organizations are used for the redevelopment of residential areas in cites. The main goal for realizing a DDC is to create a decisive execution organization for the restructuring of the areas. To realize such an organization the parties involved need to be willing to transfer a large part of their authority to the collaboration [8]. The advantage of a DDC is that a swift decision-making process can be realized. If the development is assigned to a DDC than the decision-making process will be less complex compared to the decision-making process of municipalities and housing corporations.

\subsection{Relevant cases: best practices?}

The purpose of this phase in the research project was to find sufficient evidence in terms of best practices of successful public private joint initiatives for long term development processes. The next three cases have a few similarities. The developments all took place in the centre of cities. All three sites are closely located to the historical centre, but they are not part of it. The restructuring of the sites was needed, because problems arouse that deteriorated the quality of the districts. There is one case in Sweden, Norra Älvstranden in Gothenburg, and two cases in The Netherlands, Paleiskwartier in the city of Den Bosch and Oud Krispijn in the city of Dordrecht. In all the three cases the municipalities are closely involved in the development. They play a major part in the planning and realization of the restructuring. Within the role of the municipalities there is division created between the municipal council and the executive organization, because they want to limit the changing influence of the different parties in the city council. In all cases the ownership was transferred to the 'development company'. 
The location Norra Älvstranden is a harbour and industrial area. It is a very large area of 250 ha with shipbuilding industry and with water-related industry. The location Paleiskwartier had the function of industrial area, but the type of industry was very different from Norra Älvstranden. The location Paleiskwartier consists of much smaller plots with less heavy industry. The site is 30 ha large. Oud Krispijn is a residential area with about 3.200 houses. There is no industry located in this area.

The special purpose vehicles that were created had a different shape for each case. In the case of Norra Älvstranden the development company was first wholly owned by the national government and later transferred to the City of Gothenburg. The development company received a mandate of the municipality and functioned as a private company, but the municipality was the only shareholder of the development company. In the initial phase, it received a subsidy of the state, but further there were only investment of the market.

For the restructuring of the Paleiskwartier a development company was created with four different parties: the City of Den Bosch, KondorWessels (Contractor), NIBC (Bank) and Stichting Pensioenfonds Stork (SPS, Pension Fund). One public party and three private parties were involved in this special purpose vehicle. In the last case, the three housing corporations with ownership in the area created a District Development Company. This development company realized a cooperation agreement with the City of Dordrecht.

The following lessons were learned from the case studies.

- The company worked within the framework of local government, but set clear economic conditions. The developments were free of party politics. Within the project the profitable components were balanced with the non-profitable components.

- The company was mandated to assign the development program: to create a well-functioning mixed-use area for the long-term.

- A swift decision-making process was realized, because the company was mandated and professional to organize stakeholders' involvement processes.

\section{Preconditions for organization design}

The problems with the restructuring of business locations, the interests of the involved participants and the advantages of development companies are described. These three subjects will be the basic outlines for the design of the development company for the restructuring of industrial sites. This part describes the design of an ideal typical development company. The design of this company is stated as a business plan. The format of Mckinsey [9] is used to describe the design of the development company.

For a joint restructuring of several business locations an experimental organization design will be developed and discussed. The development company will be a Regional Development Company (RCD). It will be designed for the region Breda - Tilburg ('Breburg') with nine participants; the province NoordBrabant, seven municipalities in the region and the 'Brabants Zeeuwse Werkgeversvereniging (BZW, 'employers' organization'). The proposed RCD 
will provide a solution for the problems of the restructuring of business locations as described earlier in the research. The unique selling points should be:

- The company combines the different objectives and stakes of all the participants to one joint interest;

- The RDC has more expertise and knowledge, because it consists of nine different participants;

- The RDC removes the internal competitions between municipalities;

- The public and private areas are addressed in the policy, the master plan and the developments;

- The RDC will be responsible for the whole business site policy in the region. The company will create and be responsible for a high-quality area that provides a sustainable economic development in the region 'Breburg'. This will be of great value to the region.

\section{Vision, mission and objective}

The vision of the RDC is that public and private parties work together to create a solution for the existing, dated industrial sites and create high quality business areas for sustainable economic development in the region 'Breburg'. The mission of the company is that the company will realize solutions for the restructuring of business locations in collaboration with the involved parties in the region Breburg. The main objective of the RDC for the restructuring of business locations is: Integrally restructure dated, existing business locations in collaboration with the involved participants in the region 'Breburg'.

\section{Organization design}

The scheme in figure 1 shows which participants contributed capital to the RDC. It indicates that the RDC operates on the basis of a revolving fund. This means

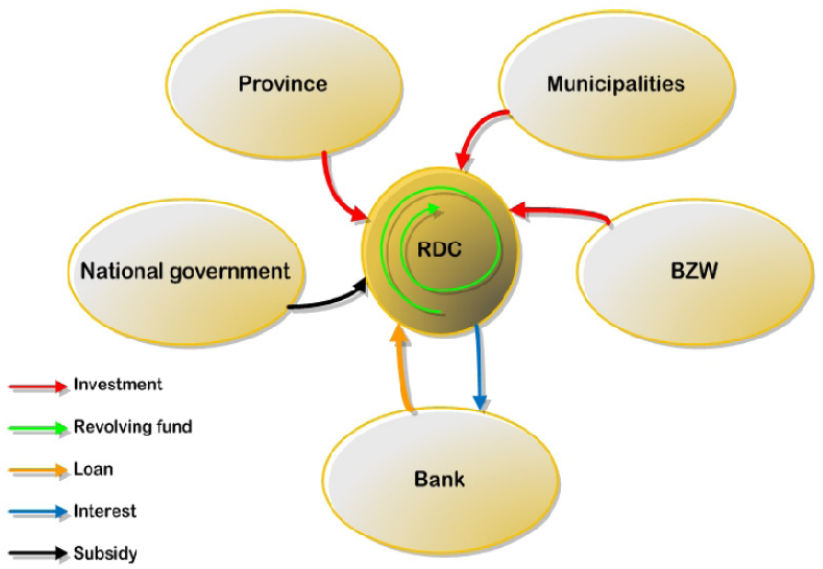

Figure 1: Concept of the business model for a Regional Development Company. All the participants are addressed which are involved in the RDC. 
that the company can operate independently after the first contribution of capital and that the return of the activities is invested in the company.

\subsection{Organization of RDC-Breburg}

A distinction is made between shareholders and stakeholders of the RDC. See figure 2. The shareholders of RDC are the province, seven municipalities and BZW. The nine shareholders will own the company. Each shareholder has the same voting right. The nine shareholders all have their own interest, which have to be unified to realize the objective of the company. The national government and investors are both stakeholders for the RDC. The national government is interested in the restructuring of industrial sites that will improve the quality of existing sites. Investors are only interested in business locations if they provide possibilities. There will have to be clear and interesting opportunities related to the restructuring in order to get the investors more active involved and 'shared'.

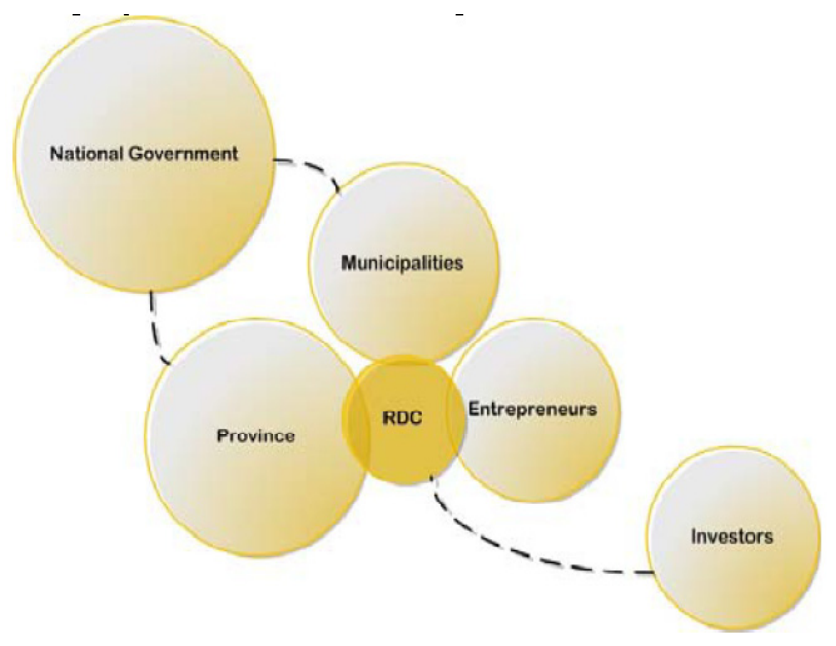

Figure 2: $\quad$ Shareholders and stakeholders related to the RDC.

The RDC consists of a management and an executive organisation. The holding executes the policy and the master plan determined by the shareholders. The holding realizes activities necessary to execute the policy and the master plan. The holding also facilitates the operation companies. The operation companies execute the determined projects in the region of 'Breburg'. The basic scheme of this organization approach is given in figure 3. 


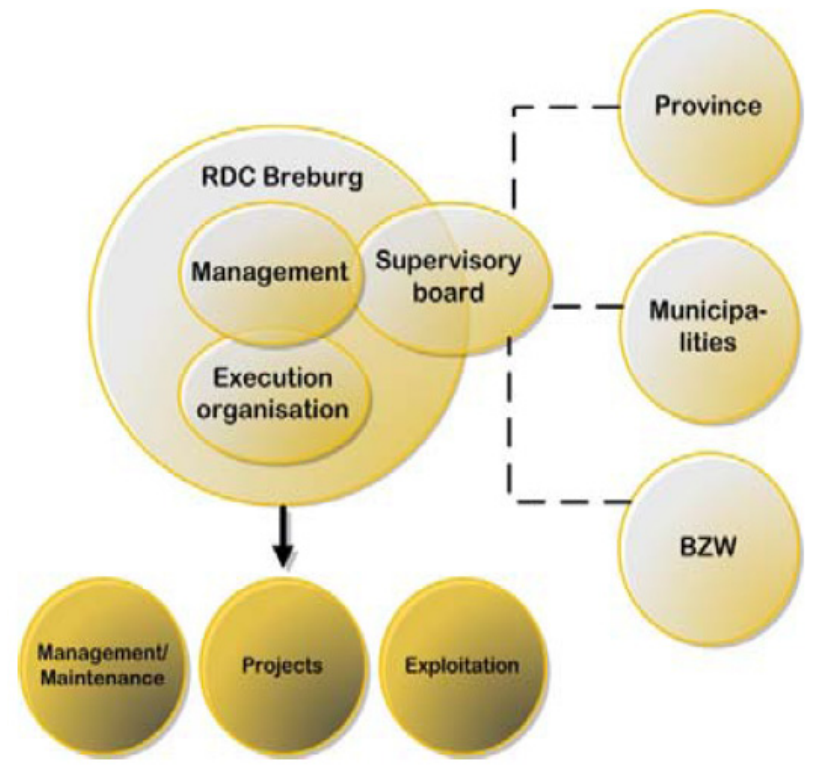

Figure 3: Organization scheme with holding and operation companies.

\subsection{Financial outlines}

In this part the financial aspects of the RDC are described. Of all business locations in the region 40 sites with a total surface of 1.726 ha are dated. That is $49 \%$ of the total surface of business locations in the region 'Breburg'. The company will also perform management tasks and maintenance for these sites. It will take over these tasks from the municipalities. It is assumed that the budget of the municipalities is transferred to the company. The first table gives an insight in the expected costs of the different activities, and the second table gives an insight in the expected return of the RDC.

In the estimation of the total return the amount of the exploitation is added to the rest of the amounts, because the exploitation provides more return than the allocation of new sites. With the activities the RDC will be able to realize a return of approximately 235 million Euros. That is $22 \%$ of the costs needed for the restructuring assignment. If the shareholders each invest an amount of 9,8 million Euros during the period of eleven years the RDC will be able to attract $70 \%$ foreign capital for the execution of the restructuring and the other activities.

One main assumption is that the company has a revolving fund. This means that the revenues/profits are invested in the activities of the RDC. This is necessary, because the restructuring is very expensive and will need additional funds. These funds can be realized with the other activities of the company. Only if the profits will rise above the level needed for the restructuring it will be distributed to the shareholders. The profits will be paid according to the amount they have invested. 
Table 1: $\quad$ Expected costs.

\begin{tabular}{|c|c|c|c|c|}
\hline Activity & Hectare & Cost/hectare & Total costs & Source \\
\hline Revitalization & 844,87 & $€ 230.000$ & $€ 194.320 .100$ & $\begin{array}{l}\text { Noordanus, } \\
2008\end{array}$ \\
\hline $\begin{array}{l}\text { Heavy } \\
\text { revitalization }\end{array}$ & 56,96 & $€ 1.000 .000$ & $€ 56.960 .000$ & $\begin{array}{l}\text { Noordanus, } \\
2008\end{array}$ \\
\hline $\begin{array}{l}\text { Re-stressing the } \\
\text { distinctive } \\
\text { features }\end{array}$ & 47,47 & $€ 1.400 .000$ & $€ 66.458 .000$ & $\begin{array}{l}\text { Noordanus, } \\
2008\end{array}$ \\
\hline Transformation & 86,30 & $€ 8.800 .000$ & $€ 759.440 .000$ & $\begin{array}{l}\text { Interview: } \\
\text { Fokkinga, } \\
2008\end{array}$ \\
\hline Total & 1035,60 & & $€ 1.077 .178 .100$ & \\
\hline
\end{tabular}

Table 2: $\quad$ Expected returns.

\begin{tabular}{|c|c|c|c|c|}
\hline Activity & & Hectare & Return/hectare & Total return \\
\hline Revitalization & & 27 & $€ 100.000$ & $€ 2.700 .000$ \\
\hline $\begin{array}{l}\text { Re-stressing } \\
\text { distinctive features }\end{array}$ & the & 47,47 & $€ 0$ & $€ 0$ \\
\hline Transformation & & 86,30 & $€ 0$ & $€ 0$ \\
\hline $\begin{array}{l}\text { Management } \\
\text { maintenance }\end{array}$ & and & 4234 & $€ 1.500$ & $€ 6.351 .000$ \\
\hline Allocation new sites & & 734 & $€ 150.000$ & $€ 110.100 .000$ \\
\hline Exploitation & & 734 & $€ 153.216$ & $€ 112.460 .544$ \\
\hline Additional & & 310,68 & $€ 160.000$ & $€ 49.708 .800$ \\
\hline Subsidy & & 1035,60 & $€ 61.550$ & $€ 63.741 .180$ \\
\hline Total & & & & $€ 234.961 .524$ \\
\hline
\end{tabular}

\section{Simulation}

The experiment was executed to test the design of the Regional Development Company. Therefore a simulation has been done by means of a negotiation event with seven parties. The province, three municipalities, the entrepreneur, the investor and the developer have been represented in this simulation. The objective of the negotiation meeting was to realize three projects. The first project was dealing with a revitalization of the business location, the second project with a transformation of a business location, and the third project with an allocation of a new business site in the municipality.

In order to understand the possible benefits and pitfalls of the design of the RDC the negotiation meeting was realized in two ways. In the first round the current process and approaches for the redevelopment of business sites was followed. In the second round the organization of the RDC was 'available' for the participating parties. 
A comparison can be made between round 1 and 2 . In round 1 the seven parties discussed the possibilities together. But the objective was not realized, which was not really surprising. As in many real world situations, the parties were not committed and did not know each other's interests. In round 2 the meeting was focused upon the collaboration of the five parties in the RDC. In this round the objective has been realized. This can be the result of the RDC, because the five parties had the same interests. It is noted that in this round the developer and the investor believed that they were excluded from the negotiations. They had the idea that the RDC was non transparent.

Because of the limited set of tests the outcomes of these testing rounds for the design for the RDC can only be interpreted as indications for future organizations' designs. It was interesting to observe that the performed simulation offered an implicit basis for communication between a set of real world representatives about many real-world aspects. The need for a RDC looka-like was recognized without doubt.

\section{Conclusions}

The research has provided insights into the problems of the restructuring of business sites in The Netherlands and different shapes of development companies. The research has resulted in a design of the Regional Development Company Breburg for an integral approach of the restructuring of business locations. It has been a research with a wide spectrum. It is necessary to execute additional research about the following topics to make a better judgment of the usefulness of the RDC Breburg.

This research has been focused on the organizational and financial aspects of development companies. It will be useful to execute additional research about other aspects of development companies, like the legal aspects, the decision process and the appropriateness. The politics and the hidden interests of the stakeholders of the restructuring of business locations have not been considered. These issues will have a great impact on the creation of the RDC. It is very valuable to execute further research about these topics; for example, to conduct more interviews with the involved parties about policy and political issues in the region.

The Regional Development Company consists of a holding with operating companies. The design of the organization is focused at the level of 'the holdingcompany'. Further research is needed for the organizational, financial and legal aspects of the operating companies, in order to extend the design of the RDC to the operating level. A financial estimate has been made to determine the capital needed for the activities of the company. Extra research is needed to make the financial estimate more explicit. It would be very attractive to determine explicitly the costs and revenues of all the activities of the RDC.

A unique selling point of the company is that it will create and be responsible for high quality business sites which will stimulate economic activities in the region. Additional research is required about this topic to determine whether value capturing approaches can be used for additional financing. 
The simulation experiment was useful to understand the concept of the RDC organization. Because of the limited set of tests the outcomes of these testing rounds for the design for the RDC can only be interpreted as indications for future organization designs. It was interesting to observe that the performed simulation offered implicitly a basis for communication between a set of real world representatives about many real-world aspects. The need for a RDC looka-like was recognized without doubt.

\section{References}

[1] ITSO, 2004, "Pilot herstructurering ITSO: herstructurering van bedrijfsgrond, de ondernemer centraal", The Hague

[2] Noordanus, P.G.A., 2008, "Kansen voor kwaliteit: een ontwikkelingsstrategievoor bedrijventerreinen", Taskforce (her)ontwikkeling bedrijventerreinen, Ministry of VROM and Economic Affairs.

[3] Louw, E. and Bontekoning, Y., 2006, "Planning of industrial land in the Netherlands: its rationales and consequences", Tijdschrift voor Economische en Sociale Geografie, vol. 98, no. 1, pp. 121-129

[4] VROM-raad, 2006, "Werklandschappen: een regionale strategie voor bedrijventerreinen", The Hague

[5] Rob Gordon, Director Business locations, BOM, 4 July 2008.

[6] Metselaar, C., (2008, July 2), Advisor Business Locations, 2W4. (J. Braas, interviewer)

[7] Blokhuis, E.G.J. and Schaefer, W.F., 2006, "Identificatie van herstruktureringvraagstukken: bedrijventerreinen in Nederland", Eindhoven University of Technology

[8] Apperloo, W., Ophem, I. van, Hulshof, M. and Kort, M., 2003, "Monitor: Wijkontwikkelingsmaatschappijen, eindrapportage", Berenschot groep B.V., Ministry of VROM and KEI kenniscentrum

[9] McKinsey \& Company Inc., 1998, "Starting-up: companies for tomorrow", Amsterdam 